\title{
Trends, challenges and opportunities for LIS education and training in Eastern and Southern Africa
}

\author{
Dennis Ocholla \\ Theo Bothma \\ Dennis Ocholla, University of Zululand, KwaZulu Natal, South Africa \\ Theo Bothma, University of Pretoria, Pretoria, South Africa
}

[Tables at the bottom of the document]

Purpose - The purpose of this paper is to discuss the status, trends and challenges of library and information education and training in Eastern and Southern Africa. It notes that library and information education and training in Africa is undergoing rapid change, with difficult challenges to be overcome. For example, during the past 20 years, the number of library schools has grown in some regions and declined in some, such as South Africa. Common LIS factors include amalgamation, re-orientation, and curriculum review and revision.

Design/methodology/approach - The authors' extensive experience with and exposure to LIS education has been used together with observations and literature survey in the field to inform this paper.

Findings - It is evident that LIS schools have, to a greater or lesser extent, been redesigning their curricula to keep track of the latest developments in the information world and keep their teaching market-related. New qualification programmes have been developed to provide opportunities for further specialization. In many cases departments have changed their names to reflect these new focus areas and extensions, and in many cases departments have realigned themselves within their universities. It is evident that LIS schools have taken the challenges of the changing information environment very seriously, and have adapted their curricula, their names and their institutional alignments to reflect these changes.

Research limitations/implications - The paper raises fundamental issues concerning trends, challenges and opportunities for LIS education and training in eastern and southern Africa by largely drawing examples from the authors' experience and related African studies in the domain.

Practical implications - The paper provides useful current information to inform LIS educators, researchers, students and other stakeholders on the issues and challenges of 
LIS education in the region.

Originality/value - Information provided in this paper is of value for comparative studies on LIS education and training. The paper is current and largely informed by participant observation, participation and experiential knowledge that is fresh and well informed.

\section{Introduction}

The aim of this paper is to discuss the status, trends and challenges of library and information education and training in Africa. The authors have used their extensive experience with and exposure to LIS education, observations and relevant literature in the field to inform this paper. Africa consists of 53 independent countries. A large portion of contemporary Africa is influenced by its colonial past, and the negative aftermath of periods of invasion, war, servitude, divestment, racial segregation, illiteracy, poverty and the denigration of indigenous communities. Positive aspects, often overlooked, include the developmental infrastructure that, though not initially intended to benefit Africans, later cemented foundations on which some of the current developments thrive. One such foundation is language as, apart from local languages, 26 are English speaking (Anglophone), 29 French speaking (Francophone), five Portuguese speaking (Lucophone), seven Arabic speaking and two Spanish speaking. Knowledge of these languages has provided Africans with leverage enabling participation in global knowledge and information production, consumption and sharing. Libraries and Library and information education institutions also began early on the continent. Apart from South African LIS schools, started as early as 1938 (see Ocholla, 2000, p. 35; Sitzman, 1988). LIS education in Africa began after 1960. By the 1980s there were five main LIS education institutions based in Ghana, Nigeria, Senegal and Uganda (Ocholla, 2000, p. 35; Sitzman, 1988; Bock, 1987; Aina, 1995; Gupta and Gupta, 1993) and 18 in South Africa (Ocholla, 2000, p. 35; Raju, 2005). Although current LIS education in Africa does not exclusively target the training and education of librarians, originally, LIS schools' major focus in the education and training area was librarianship. A significant growth in the number of LIS schools is noted in Anglophone Africa, slight growth in Francophone and Arabic oriented countries, and unknown growth in Lucophone speaking countries (e.g. Angola, Cape Verde, Guinea Bissau, Mozambique and Sao Tome et Principe). The growth of Library schools in South Africa is shaped by periods of significant quantitative growth from 1938 to 2000, rising from one LIS School to 18 (Van Aswegen, 1997; Ocholla, 2000, p. 36; Raju, 2005), to a notable decline from 2000 to 2006 (from 18 to 11). The latter was caused largely by the transformation of South Africa's education sector, which led to the merger of many Higher Education Institutions (HEIs) and a review of their structure in terms of programmes/qualifications offered within the institutions. A significant growth of LIS schools is noted in Nigeria, Kenya and Tanzania. In Southern Africa, at least one LIS School is found in Botswana, Malawi, Namibia, Zambia and Zimbabwe. The remaining countries have either one LIS school, or none (see Table I and Table II). Most LIS Schools are located within HEIs or universities, ensuring that curriculum development and quality control is adequately 
monitored and evaluated. This is both despite and in addition to the presence of National qualification authorities (such as the South African Qualification Authority (SAQA)). There is evidence that LIS qualification programmes have kept a minimum number of credit and content requirements for LIS education, such as management, information seeking and retrieval, knowledge organization, knowledge representation and user studies, with an increased use of technology. LIS curricula also increasingly provide core courses or electives/auxiliaries in knowledge management, multimedia, publishing, records management, information and communication technologies (see Aina, 1995;

Gupta and Gupta, 1993). The contact teaching mode is widely used with minimal distance teaching (which is the dominant teaching mode at the University of South Africa (UNISA)).

There are two dominant learning models for librarianship qualification in South Africa, namely, the undergraduate model and the post-graduate diploma model. The undergraduate model is the most common model used in South Africa, consisting of three to four years of study, during which topics from the broad field of library and information science are combined with a number of compulsory and/or elective courses from other disciplines. This may then be followed by an Honours degree (one year), during which students specialize in topics on library and information science. In the post-graduate model, students are expected to obtain any general degree as an admission requirement to the post-graduate diploma in library and information science. The post-graduate diploma is then followed by an Masters degree. This model is followed by both the Universities of Cape Town and KwaZulu-Natal. There are obviously advantages and disadvantages to both these models. The most significant disadvantage of the former is that students do not have a broad-based general education before beginning their LIS studies; the study time, however, is shorter, and the costs to qualify as information professionals, lower. The disadvantages of the latter are: time, as it takes considerably longer to obtain a formal qualification in LIS than in the former model, and the costs are considerably higher; however, students do have a broad-based general education. The advantages/disadvantages of the two models are therefore in reverse, and it is only above and including Honours level that there are no differences between the models.

Undergraduate education programmes (either as degree or post-graduate diploma) in all departments are followed by post-graduate programmes. In both cases, students obtain sound theoretical and practical knowledge of LIS topics before they begin their postgraduate LIS studies. Three-year programmes are usually followed by a fourth year, typically named an Honours programme. This, in turn, leads to a Masters programme, which in most cases can either be offered through coursework or research. The coursework Masters, is a specialization during which students study selected LIS topics in depth. The four-year undergraduate degree programme leads to Masters degree or Honours degree. Masters programmes are followed by doctoral by research programmes. However, not all departments/schools offer doctoral programmes (see Table I). 


\section{Overview of trends}

Essentially (see Ocholla, 2005 and Minishi-Majanja, 2004), common trends are noted in the: growth of LIS schools, review and revision of curricula, increased use of ICTs (information and communication technologies), rise and fall of student numbers, amalgamation and re-orientation (for example University of Johannesburg and the University of Stellenbosch) of LIS programmes, relocation of the academic administration of LIS schools (for example, information science at the University of Pretoria), expansion and closure.

\section{Expansion and closure}

The closure of LIS schools in Africa has occurred largely in South Africa during the last ten years. However, in other parts of Africa, and during the same period, the number of LIS schools has either remained the same or increased. This latter trend is evident in East African countries such as Kenya, Tanzania and Uganda, which have experienced an increase in the number of LIS schools in the region. In southern Africa, the number of LIS schools in Botswana, Namibia, and Zambia has remained the same. New LIS schools have emerged in Malawi and Zimbabwe. There are no reported cases of LIS schools existing in Mozambique, Lesotho or Swaziland, although a plan to establish a LIS school in Lesotho exists. South Africa is the only country in Southern Africa that has witnessed a drastic reduction in its LIS schools during the last ten years, from 18 to the current 11, with further possible closures (e.g. the prestigious LIS school at the University of Cape Town, which is due for closure in 2010, unless drastic steps are taken). The reduction of LIS schools has largely been caused by the transformation of the higher education sector in South Africa, which has led to the downsizing of some HEIs and creation of new structures for institutions mainly through the merger and re-orientation of academic departments. In West Africa, the number of LIS schools has significantly increased, especially in Nigeria. Other countries such as Ghana have retained the original number of schools (see Ocholla, 2000). The authors were unable to establish the number of LIS schools in Francophone, Lucophone and Arabic speaking parts of Africa. However, the general trend appears to signify that LIS schools are increasing, and new schools emerging either in the same countries or in countries that previously never had a LIS school.

\section{New names and realignment}

In the past, most departments were simply called Departments of Library Science/Library Studies or Librarianship. In the 1980s, most departments changed their names to Department of Library and Information Science/Studies. The 1990s again saw departments change their names to Information Science/Studies. By combining with other (information-related) disciplines, some have incorporated this in their names as well, for instance the Department of Information and Communication Studies at the 
University of Namibia, or the Department of Information and Knowledge Management at the University of Johannesburg.

Traditionally, LIS schools formed part of a faculty of Humanities, or Social Sciences. This still tends to be the case. However, again to reflect the changes in focus, some departments have moved to other faculties or schools. For example, the LIS programmes at the University of Cape Town are offered by the Centre for Information Literacy in the Centre for Higher Education Development. Within the University of Johannesburg, the department forms part of the Faculty of Management, and in the University of Pretoria, the department is a member of the School of Information Technology (with Computer Science and Informatics (Information Systems)).

These changes all reflect a shifting information landscape, affecting change in the focus areas of departments.

\section{Categorization of LIS schools and academic programmes and dispensation}

Categorization of LIS Schools qualifications may summarily be viewed in five ways: the nature and type of qualifications programmes offered (e.g. Bachelor or Masters degree); the duration and credit requirements for a qualification (e.g. three or four years); the academic level of the qualifications (e.g. undergraduate or graduate); the mode of instruction (contact or distance); and the orientation of the LIS school (e.g. vocational or general education). Notably, university based LIS schools offer more general or theoretical education, and also offer undergraduate and post-graduate degree qualifications which take three to four years for undergraduates, and a minimum of one to three years for Honours, Masters and Doctorate qualifications respectively. The mode of instruction is mainly contact; distance education is insignificant. The LIS qualification programmes offered at the Universities of Technology (formerly called Technikons in South Africa) and Polytechnics offer vocational education and training qualifications which take one to two years for certificates and three to four years for Diploma and Higher Diploma, or Bachelor of technology qualifications. As in universities, the mode of instruction is mainly contact. Common qualification programmes focus on LIS education and training for library workers. A large number of institutions focus on other related information fields such as publishing, records management, multimedia, information technology and knowledge management, either as autonomous qualifications or as integrated disciplines within a holistic LIS qualification, as strongly witnessed in the Universities of Botswana, Pretoria (South Africa), Ghana, Moi (Kenya), Makarere (Uganda), KwaZulu-Natal (South Africa).

\section{Limited training in library science}

Although initial LIS schools in Africa focused on the education and training of librarians for work in libraries, the focus of current LIS schools in the region has grown more diverse as libraries alone are unable to provide enough job opportunities for LIS 
graduates. Hardly any new libraries are built. Those existing are unable to offer enough employment with insufficient funds, a shortage of appropriate posts/vacancies to accommodate college/university graduates and low salaries; library management structures do not prioritize libraries for further development. Libraries are also facing stiff competition from emerging information provision centers and services, particularly technology-driven services such as the internet and wireless technology, whose proximity to information seekers and relevance of content is increasingly rendering library services irrelevant to most people. Sadly, all these developments are happening to an old information service provision centre (library) that has not created a niche area for itself in the deprived community that has always marginalized the majority of the population in Africa because of its elitism, urban-centrism and Euro-centrism as noted in studies (e.g. Issak, 2000; Sturges and Neill, 1990) arguing that libraries in Africa are largely stocked with western literature that are written in non-African languages. The libraries collection rarely address Africa's context or readers information needs and they are few and located far away from those who could benefit from their services. The authors believe that these factors have, to a large extent, contributed to the declining student number in LIS schools for librarianship on the continent. For instance, most LIS schools in South Africa have reported a sharp decline in student enrolment for librarianship. Responses to this situation have varied. Some LIS schools have closed librarianship programmes completely, others have changed the names of their departments, a lot more have diversified their qualification programmes by providing additional qualifications in related information areas such as knowledge management, multimedia, records management, publishing, information technology etc., whilst others have enriched their curricula by adding market-oriented courses and/or academic subjects. In essence, many LIS schools no longer target libraries alone, but a broader information or emerging market.

There is, nevertheless, evidence that LIS qualifications have kept a minimum number of credit and content requirements for LIS education such as management, information seeking and retrieval, knowledge organization, knowledge representation and user studies.

Examples are as follows:

- In the advanced diploma at the University of KwaZulu-Natal, the following is offered: "Descriptive cataloguing, information sciences and agencies, management of information agencies, information users and use, information delivery systems, information searching and retrieval, subject analysis, automation of information centers, information and communication technologies, records and documents management” (www.hs.unp.ac.za/infs/course3.htm).

- Within the University of Zambia courses on indexing and abstracting, cataloguing and classification, collection development, records management, special libraries and information centres are offered (www.unza.zm/schools/education/lis/lisprog.htm).

- Moi University in Kenya offers courses on cataloguing and classification, records management, collection management, user studies, subject indexing and thesaurus construction (www.mu.ac.ke/academic/schools/is/curri.html). 
- Makerere University in Uganda, in the East African School of Library and Information Science, has a programme that also contains courses on abstracting and indexing, cataloguing and classification and records management (www.makerere.ac.ug/easlis/programs/blis.html).

- Similar course content is offered at the University of the Western Cape (www.uwc.ac.za/arts/libinf/index.htm).

- At the University of Cape Town, the post-graduate diploma offers "traditional" LIS topics, e.g. user groups and information use, information resources, information tools and skills, performance evaluation and resource management, expanded by more technology and management oriented modules (e.g. databases and database production, organizational behaviour and development, strategic planning) (www.ched.uct.ac.za/cil/dils/pgdiplis.html).

- Similar trends can be observed at other universities still offering Library Science as an option, e.g. the University of Pretoria (http://is.up.ac.za), the University of Namibia (http://www.unam.na/faculties/humanities/ics/libstudy.html) and the University of Botswana (2005/2006).

Thus, not much has changed in terms of the core LIS subjects in selected African countries reported by Ocholla (2000, pp. 38-39)

\section{Expansion of broader information science topics}

Even though the distinction between library science and information science is unclear and fuzzy at best, it is evident from a perusal of curricula at the various universities that there are a number of new topics being phased in at most universities. These include courses dealing with information technology, the information society, legal, ethical and economic aspects of information, and information and knowledge management.

There is evidence that there is an increased integration of information technology in LIS curricula. Courses on computer literacy, ICT, hardware and software (for LIS and in general), databases, information systems and systems development can be found in most curricula. In most cases, the study of ICT is conducted in support of information work, e.g. understanding computers and networks in order to facilitate online information retrieval. However, courses are to be found in computer programming, operating systems theory and computer architecture (e.g. at Moi, www.mu.ac.ke/academic/schools/is/curri.html), as well as courses on website design and development (e.g. the Universities of Johannesburg, www.uj.ac.za/infoman/index.asp?page=detail\&id=956, and Stellenbosch, http://0academic.sun.ac.za.innopac.up.ac.za:80/infoscience/socio-informatics/under.htm).

Courses on the information/knowledge society, globalization, information/communication for development are found at the Universities of Pretoria, Namibia and Cape Town, Courses on information ethics, law, philosophy and economics are found at the University of Pretoria. Most programmes include courses on information management. 
Electives, as part of the programme in LIS, often include communication or media studies, and publishing (e.g. the University of Namibia and Moi and Makerere Universities).

\section{Importance of information and knowledge management}

Within LIS schools. Information management is found in different formats, as part of most - but not all - LIS programmes at undergraduate level. Very often this is expanded to include information and knowledge management, or even separate, specialist modules on knowledge management. Typical topics in information and knowledge management (e.g. at the University of Pretoria) include personal information management, tools and techniques for information and knowledge management, strategy formulation and implementation, information and knowledge audits and information consultancy; theoretical models are also studied in detail. Thus, knowledge management courses appear to be provided either as autonomous courses, or units within an existing management course, or as a qualification programme of its own within or outside an LIS school.

\section{Developments at the Universities of Johannesburg (UJ) and Stellenbosch (US)}

These two institutions provide an example of LIS schools abandoning their original mandate and replacing it with an entirely different construct (perhaps to remain viable). Within the Universities of Johannesburg (UJ) and Stellenbosch (US) traditional LIS programmes have been replaced by information and knowledge management.

The University of Johannesburg's department has changed its name to Information and Knowledge Management, and moved from the Faculty of Humanities to the Faculty of Management. Two programmes are offered, namely, a BA in Information Science and a BCom in Information and Knowledge Management. The aim of the BA programme is to educate:

[...] students in the ability to obtain, manage and communicate information, emphasizing the electronic environment such as the internet and Worldwide web. South Africa is well on its way to become an information society and information management will play an important role in this regard. Course modules such as personal, organizational and strategic information management prepare students to use information as an important resource in the decision-making process (www.uj.ac.za/infoman/index.asp?page=detail\&id=956).

The BCom programme aims to: 
[...] provide students with intellectual competencies and practical skills in the application of information and knowledge management principles in the different functional units of an enterprise. South African enterprises today operate in a global market with an increasingly turbulent and volatile environment, and must withstand the competitive pressure both from other producers as well as from new alternative technologies and products. In this environment of uncertainty, information and knowledge management offer opportunities for innovative managers to use information as a strategic tool for competitive advantage (www.uj.ac.za/infoman/index.asp?page=detail\&id=952).

"Traditional” information science topics, such as information seeking and retrieval, information economics, information entrepreneurship etc. are still offered (although there are no "traditional" library science topics). Yet, the emphasis in both programmes is on (strategic) information and knowledge management, and World Wide Web (WWW) and intranet management. (The main difference between the programmes is the electives with which the information science modules can be combined.)

Within the University of Stellenbosch, the Department of Information Science has changed the name of its courses in information science to socio-informatics, and offers (among others) a BA in socio-informatics. Socio-informatics is defined as a discipline that:

[...] deals with the productive synergy between the world of human beings, organizations and their management, and the world of informatics and knowledge and decision-making technologies (http://0-academic.sun.ac.za.innopac.up.ac.za:80/infoscience/socioinformatics/index.htm); Socio-informatics deals with the triangular relationship and interface between information needs and practices, the knowledge economy and society, and knowledge dynamics in computer technology. The primary aim is to understand the implications of this for personal, organizational and social development and competitiveness. The programme focuses not only on theoretical aspects, but also on the practical needs of information specialists and knowledge workers. Three possible professions are anticipated, namely information management, electronic publishing, and data organisation and retrieval. For all of these functions computer technology offers the necessary infrastructure, and as such it is studied as a separate area of interest, but also integrated with the other themes. Further focus is supplied by the study of sociotheoretical perspectives on the contemporary knowledge economy and society, as well as basic organizational knowledge management (http://0academic.sun.ac.za.innopac.up.ac.za:80/infoscience/socio-informatics/under.htm).

There are some "traditional" information science topics retained in the curriculum. However, the focus is very much on information and knowledge management, information technology and multimedia, decision-making and value studies.

Both these universities offered programmes in library and information science in the past. In both cases, the focus changed to information science some years ago, and library science (both as a programme and as courses within the information science programme) was dropped. At present, the focus has changed again. 


\section{Information literacy}

The Association of College and Research Libraries (2000, pp. 2-3) defines information literacy as "a set of abilities requiring individuals to recognise when information is needed and have the ability to locate, process, and use effectively the needed information. Information literacy forms the basis for lifelong learning”. Information literacy is becoming increasingly popular in HEIs and LIS Schools in South Africa, mainly because it has been recognized as essential for life-long learning, and supporting students coming from information deprived environments or communities (whose number is rapidly increasing in HEIs throughout the country). There are strong information literacy programmes at the Universities of Cape Town, Pretoria and KwaZulu-Natal in South Africa. Information literacy programmes are normally offered or coordinated by LIS schools in the HEIs where they exist, and usually form part of the LIS programme only. However, in some cases, information literacy courses are available to other students at the university, such as at the University of KwaZulu-Natal, where the student:

[...] will become familiar with a range of the most commonly used information sources and will acquire skills necessary to access these sources. [They] become acquainted with the latest computer-based technological developments such as CDs, e-mail and the internet [and] learn about other information agencies and their role in the provision of information. [They have to] understand the concept of information and how the information explosion came about. Finally, [they have to be] in a position to critically evaluate the information [they] find and use (www.hs.unp.ac.za/infs/course0.htm).

At the University of Pretoria, the course in information literacy is a compulsory creditbearing semester course offered by the Department of Information Science to all first year students enrolled at the university (more than 6,100); it is a very practical, hands-on course that deals with information resources (both paper-based and electronic), principles of information retrieval (including concept identification and Boolean logic), practical information seeking and retrieval on the internet, online databases and electronic journals, copyright, plagiarism, referencing techniques, evaluation of information and writing an assignment. (This course follows on a similar course on computer literacy, also compulsory for all first year students.)

\section{Expansion of the curriculum}

In order to enrich the LIS curriculum and make it more relevant to the market, as well as attracting more students, LIS curricula have been expanded both within and outside the existing programmes.

Computer troubleshooting skills. One of the requirements for a driver's licence is knowledge surrounding basic vehicle mechanics, such as changing a flat tyre. Similarly, computer users or operators, particularly in an environment where computer repair centers are minimal or non-existent, should acquire computer trouble shooting skills essential for the basic repair of computers. Experience indicates that most computer- 
oriented problems are minor, and can be resolved by users who know basic computer trouble shooting skills. Such a course is offered in the BA (information science) programme at the University of Zululand to equip students with skills for basic computer repairs enabling the un-interrupted use of computers. Interestingly, students from this qualification programme use this skill to earn a living (see www.lis.uzulu.ac.za).

Multimedia. At a number of universities, multimedia topics/subjects are included either as electives, or as compulsory modules, which form part of the LIS or information science degree. Illustrating this is the University of Stellenbosch, at which students have to take quite a number of multimedia modules as compulsory modules for their degree in socio-informatics. The University of Johannesburg similarly stresses the management of multimedia and web environments in its degree programmes. At the University of Zululand, students can specialize in multimedia, in addition to their standard information science courses; students may therefore choose web design and development (including HTML, XML and related technologies) as a specialized stream from first- to third-year.

The University of Pretoria also includes multimedia topics/courses as part of compulsory modules for the IS programme, but multimedia has also been developed as a fullyfledged degree qualification/programme. In this instance, students do a full major in multimedia and computer science, in addition to doing information science, language and visual design courses. Multimedia topics include the theory and practice of multimedia and hypermedia, multimedia technologies, human-computer interaction, web design and development (including HTML, XML and related technologies at a very advanced level) and computer game design, etc. Practical include developing sophisticated web sites (XML-based), video and sound editing, animation with Flash and 3D Studio Max, computer game design in Macromedia Director, etc.

(http://is.up.ac.za/academic/programmes/BIS_mm.htm). At the end of their studies, students are multimedia programmers with a very high understanding of information organization and structure, and a feel for visual design and language.

Media and publishing studies. A number of universities offer courses in media and publishing studies as part of their programmes in LIS. At Moi University, for example, there are a number of such compulsory modules in the first three years, and students are offered the option of doing Publishing Studies as a specialization in their fourth year (www.mu.ac.ke/academic/schools/is/curri.html). At Makerere University, publishing and book trade is offered as a specialization

(www.makerere.ac.ug/easlis/programs/blis.html\#cou).

LIS degrees from the University of Namibia are offered in the Department of Information and Communication Studies, with the additional offer of specialized programmes in media studies. These students take a number of information science topics as part of their media studies programme, such as information and knowledge management and electronic information sources and the internet (www.unam.na/faculties/humanities/ics/mstudies.html). 
The University of Pretoria has witnessed the evolution of publishing studies out of information science into a separate programme. In addition to a number of information science topics, students study publishing management, commissioning, marketing and sales, copy-editing, design and production (http://is.up.ac.za/academic/programmes/BIS_pub.htm).

Information \& communication technologies (ICT). To a greater or lesser degree, all programmes make provision for compulsory modules in ICT (as indicated above). However, in a number of cases, a specialization in ICT is offered, such as at Moi University (www.mu.ac.ke/academic/schools/is/curri.html) where the focus is on programming skills (i.e. combining information science with computer science), and the University of Zululand, where students may specialize in computer trouble shooting skills.

Within the University of Botswana, a degree in information systems is offered by the Department of Library and Information Studies. A number of information science topics are studied, including information and knowledge management, and information retrieval, in addition to systems analysis and design, web management, databases, decision support systems, electronic commerce, human-computer interaction, networks and basic programming (University of Botswana, 2005/2006).

At the University of Pretoria an interdisciplinary four-year programme in information technology exists within the School of Information Technology. Students take three majors for this programme, namely, information science, computer science and informatics (information systems) as well as a number of multimedia courses (www.up.ac.za/academic/ebit/schoolit/academic/ung.htm\#BIT).

Records management. Another subject that has become increasingly popular in LIS schools is records management. In some institutions records management is offered as a fully fledged degree qualification programme (e.g. University of Botswana, Moi University (Kenya), University of Kwazulu-Natal (see Table I)) or courses/modules within a larger degree programme common in most qualification programmes in LIS Schools (e.g. Universities of Zululand, Pretoria, Namibia, Makarere, Zambia, Zimbambwe, etc.).

\section{Typical course content}

University of Zululand. The LIS curriculum at the University of Zululand offers six programmes: Bachelor of Library and Information (pending suspension as a result of low student numbers), Bachelor of Arts in Library and Information Science, Honours Bachelor of Library and Information Science, Postgraduate Diploma in Library and Information Science (currently suspended/archived), Postgraduate University Diploma in Specialized Education School Library Science, Masters in Library and Information Science and PhD (LIS). Within these programmes the curriculum (see www.lis.uzulu.ac.za) consists of the following core components: management (including 
information and knowledge management), searching and retrieval, knowledge organization, knowledge representation, information seeking and user studies, information literacy and information and communication technologies (including computer trouble shooting skills) besides other academic courses that students have to take at undergraduate level. Post-graduate Masters and $\mathrm{PhD}$ are done by thesis only.

University of Pretoria. At the University of Pretoria there are three undergraduate programmes, namely, in information science, in publishing and in multimedia. The information science programme has three options, allowing students to specialize in either information science, library science or in information and knowledge management. The undergraduate programmes are all three-year modules, followed by Honours (one year), a Masters through coursework or research and a doctoral programme (DPhil or $\mathrm{PhD}$ ) through research.

In the information science category at undergraduate level, students study information society, information organization and retrieval, information representation, information and knowledge management, information economics, ethics and law, information for development and ICT, all combined with informatics (information systems). In addition to information science topics, students taking the library science option study the management of information organizations, user studies, cataloguing and classification (instead of informatics). Students specializing in knowledge management do all the previously mentioned information science topics, in addition to further topics in Informatics, and topics in human resource and business management.

Students in publishing studies and multimedia do a number of core information science topics combined with publishing and multimedia topics offered by the department. Publishing students additionally study three years of a language of their choice, visual communication and business management. Multimedia students study an additional three years of computer science, visual communication and a language of their choice (for a year). Details of the programmes are cited at the University of Pretoria: http://is.up.ac.za

Similar examples can be found in other LIS qualification programmes in the region (see Table I).

\section{Challenges}

Recent challenges and opportunities facing LIS Schools in Eastern and Southern Africa are discussed by Ocholla (2000, 2001, 2003), Minishi-Majanja (2004, 2003), MinishiMajanja and Ocholla (2003), Kigongo-Bukenya (2003) and Ocholla and MinishiMajanja (2004). 


\section{Student numbers}

Without students, LIS schools cannot exist, just as businesses cannot exist or thrive without customers. Whereas the number of students enrolling for library science has declined in most LIS schools in Africa, the number of students enrolling for LIS with diverse qualification programmes incorporating either broader information orientation or specialized information qualification programmes (such as records management, publishing, multimedia, knowledge management, information technology) has in some cases increased, and others, stabilized. Most LIS schools are offering education and training for broader information related jobs in emerging markets or markets that never employed LIS graduates before. The decline in student enrolment for Librarianship qualifications is caused by limited job opportunities in libraries as the expansion of libraries in Africa is either minimal, or in some cases, non-existent.

\section{Career opportunities}

Although libraries are reported to be the biggest employers of LIS graduates in Africa, increasingly, career opportunities in the emerging LIS markets are noted. Studies by Ocholla (2000, 2005) and Snyman (2000), focusing on career opportunities in South Africa, noted that, apart from career opportunities in libraries (which was the largest employer of LIS graduates in South Africa), there were rapidly growing career opportunities in the non-library sector or the emerging market. The emerging market has forced most LIS schools to re-orient their curricula to meet the needs of the new market in order to survive. Experience has shown that educating and training LIS graduates with more knowledge and skills in broader information disciplines is realistic, viable and rewarding. Graduates from broad LIS programmes can work in any information-related field. However, the LIS curriculum must include the core LIS subjects/courses/modules such as information and knowledge management, information storage/seeking and retrieval, knowledge organization, knowledge representation and ICTs.

\section{Funding of LIS schools}

LIS schools are largely funded by the government through their parent institutions, such as universities. In countries where LIS schools fall within lower funding clusters among other disciplines such as in South Africa, LIS schools receive much lower funding when compared to other disciplines in the applied and natural sciences. Because of rapid technological changes in the information environment, resource support is fundamental for the growth and sustainability of LIS schools. Increasingly, LIS education and training is becoming highly dependent on modern computer hardware and software, efficient internet access and connectivity, computer literate and highly skilled IT staff and well equipped computer laboratories. Unfortunately, funding of LIS schools does not meet these requirements in most LIS schools in Africa. However, South Africa, when compared to the rest of Africa, emerges stronger in terms of the funding of LIS schools. 


\section{Technology infrastructures at LIS schools}

Recent reports (Ocholla, 2003; Minishi-Majanja, 2003; Ocholla, 2005; MinishiMajanja, 2004; Minishi-Majanja and Ocholla, 2004) focusing on information and communication technologies in LIS education in Africa recognized increasing investment in ICT for LIS education in the region for teaching and learning, research, and for academic management and decision making. There are, however, disparities in the nature and level of access and use at institutional, national and regional levels. These disparities are largely caused by both economic (inadequate infrastructure and resources) and political factors (willingness to invest in ICT). Common issues range from the need for ICT policies, resource support, student and staff access (e.g. in laboratories and offices, internet access, use of ICT for teaching and learning) and access to adequate computer hardware and software licenses enabling computer literacy. LIS schools based in South Africa, however, have better technological infrastructure than in other parts of Africa, and, in some cases, are even comparable to those in developed countries.

\section{Lack of funding for public libraries}

Public libraries are known to provide jobs for LIS graduates in countries with strong library service policies. In Denmark, for example, the development and sustainability of public libraries is a major cultural responsibility of the government. However, a recent report on public libraries in Africa by Issak (2000) that provided an ontological account of trends, issues and problems of public librarianship in a significant part of Africa (ten Anglophone countries), referred to poor services, declining budgets, lack of resources, outdated materials, lack of planning, inadequate knowledge of the information needs of the users and poverty, and blamed the western model of public library systems on the poor performance of libraries. This is largely because this model assumes that library users are literate, that libraries are situated close to people/users, that collections are relevant to users and poverty is not a major issue (Sturges and Neill, 1990). Libraries in Africa are largely stocked with western literature, documents are written in non-African languages and they are located in urban centers far away from needy users. Although South African public library services were relatively better than those of the other nine countries in the survey, several authors in this collected work, suggested the provision of alternative services such as community information services, impact assessment of public library services, government commitment, improvement in the professional commitment of librarians and the provision of resources as essential areas of focus. Proper planning and funding of public libraries is a major obstacle. For example, the rapid decline of public libraries in South Africa after the 1994 democratic change has slowed down and affected not only library services and information access, but also the market for LIS graduates. 


\section{Opportunities and challenges}

Threats can easily be turned into opportunities. Fundamentally, collaboration and partnership could be forged amongst LIS institutions in a country and internationally or regionally in areas such as teaching, research, student and staff exchange, conferences and workshops, curriculum development, publications, research supervision and examination and distance teaching/research. In South Africa, for example, LIS schools have begun to meet on a regular basis and discuss issues relating to LIS education and training. Initiatives on collaboration have also been forged at the LISNET-ECSA Workshop in Kampala, Uganda in 2004. A second area of opportunity is in the development of partnership with industry/employers in curriculum development, teaching, research, publication and experiential learning. Opportunities also exist in staff development, both formal and informal, creation of a consortia of LIS schools, distance learning (e.g. at UNISA), multidisciplinary approach to LIS education and training that enables the extension of knowledge frontiers made possible by the location of most LIS schools in HEIs, market orientation of programmes, uniqueness of programmes and avoidance of harmful competition, accreditation standards, location of programmes largely within established universities, internet presence for web visibility and networking and knowledge sharing.

\section{Perceived needs of the country/the developing world}

Well-trained information professionals are essential in any country, both in the developed and in the developing world. They are employed in libraries of all kinds (school, public, special, academic), in information centres (private, public, government), as consultants to big business, as information managers, etc. There should, therefore, be a huge market for graduates of LIS, IS and other such related programmes. A consistent demand for our graduates, would translate into a demand for our programmes. For instance, in Botswana, the present department boasts approximately 600 undergraduate students in its programmes, of which approximately two-thirds are in the library and information studies programmes. This is sadly not the case in South Africa, where, as indicated before, a number of library schools have closed down in the past few years and many existing LIS programmes are under threat. Nevertheless, this presents a huge opportunity for (L) IS schools to market their programmes actively.

We also recognize opportunities for LIS workers emanating through collaboration and partnerships, human resource needs for knowledge management and information services in the government and corporate sectors, the need for relevant research and new regional initiatives such as SADC, NEPAD and East African Community (EAC).

\section{Industry requirements}

There are many ways of determining LIS market needs, some of which have been reported in studies by Ocholla (2001, 2005) and Snyman (2000). These include scanning 
newspapers for skills, knowledge and attitudes required by LIS jobs; tracer/follow-up studies of graduates, focus group discussions through committees consisting of participants from LIS schools and stakeholders from the industry (including employers), consultations and reading relevant literature, etc. Recent studies have shown that libraries, despite their low number, are still the biggest employers of LIS graduates in the region. However, the emerging market, with non-library jobs both in the public and corporate/private sectors, is rapidly growing and requiring high levels of information competency. Essentially, the LIS sector in the region requires comprehensive knowledge and skills in areas such as information literacy, information and knowledge management, information technology, information searching and retrieval, research, communication skills, customer care, the ability to work both independently and in a team, and positive work-related attitudes.

\section{Indigenous knowledge}

Indigenous knowledge and indigenous knowledge systems are an important research focus area in many developing countries. In South Africa, research in indigenous knowledge is regarded as highly important, and the National Research Foundation has identified this as one of its nine focus areas, as:

[...] we need to understand IK and its role in community life from an integrated perspective that includes both spiritual and material aspects of a society as well as the complex relation between them. At the same time, it is necessary to understand and to explore the potential contribution of IK to local development. Further, research into the protection of IK and its utilization for the benefit of its owners and the communities where it is practiced is also needed. The present status of IK is that these forms of knowledge have hitherto been misunderstood and as such suppressed. Therefore, IKS should be brought into the mainstream of explaining and understanding the world in order to establish its place within the larger body of knowledge. The socio-economic potential of IK should be considered, as should the cultural and moral values and systems of IK. Research into IKS ideally, should also be carried out with the participation of the communities in which it originates and is held as far as is practicably possible (www.nrf.ac.za/focusareas/iks/).

Very often, this research is carried out by anthropologists, biologists, botanists, sociologists, art and music experts, etc, but there is definitely a place for information professionals in this research as well, especially in terms of collecting, organizing, describing and digitizing the information, and making it accessible (e.g. via the web). This presents a unique opportunity for information professionals. However, there do not seem to be any courses that specifically train information professionals to work in these areas, and current information professionals working in these areas seem to be making use of their general (L)IS skills. Training information professionals to specialize in the field of indigenous knowledge (probably as a member of an interdisciplinary team) presents a huge opportunity for LIS schools to extend their curricula. 


\section{Opportunities for (relevant) research}

Research and development form the backbone of any profession and any teaching programme. There are many opportunities for relevant research in information-related fields in Africa. Obviously, scholars from Africa can make significant contributions to the mainstream topics in, for example, information retrieval (IR), IR system design and development, information and knowledge management and many other topics. However, Africa presents unique opportunities for research that may not necessarily be available in the developed world, or where issues may differ between the developed and developing world, and between developing countries. A few examples will suffice: indigenous knowledge and indigenous knowledge systems (as explained above), information for development, the use of ICT in the developing world, information ethics and legal aspects of information in an African context, dissemination of information in rural areas/health contexts (especially regarding the AIDS pandemic), literacy and information literacy training in a developing world, information flow between the developed and the developing world, etc. All these topics are highly relevant within the developing world, and may also radically influence the developed world in terms of its perceptions of and relationship with the developing world.

\section{Continuing education for LIS workers/professionals}

Although not current information, some of the initiatives made on continuing education so far covering Africa were reported by Ocholla (2000, pp. 43-44) and Kaniki (1997) on South Africa. There are also fresh initiatives being made in South Africa through CEPDICDC. The need and relevance of Continuing Education and Professional Development has been recognized by the Library and Information Association of South Africa (LIASA) among its four focus areas: Personal development, professional and support skills development, information and communication technology and management and leadership development, including advocacy. Continuing Education and Professional Development (CEPD) (see www.liasa.org.za/cerd/index.php) is crucial as it enables professionals to keep their practices current and relevant and involves "learning to know" and "learning to do" through "the promotion and provision of education and training for LIS workers" and "encourage the promotion of service standards and acceptable good practice”. This initiative is currently achieved through the Centre for Information Career Development (CICD) (see www.liasa.or.za/partnership/cicd.php) "to access, offer and recommend a suitable spread of relevant programs thereby ensuring the trainee has access to a variety of courses that will enhance and upgrade skills pertinent to their personal and professional development”.

\section{Continuing education for faculty members}

Redesigned curricula obviously have very serious implications for faculty members in (L)IS departments. Faculty members have to move away from their traditional comfort zones and ensure that they keep up-to-date with developments, thus enabling quality in 
teaching and research. As training courses are not always readily available, and those that are available tend to be expensive, the implications are that faculty members have to take responsibility for their own education and training, and actually educate and train themselves, through a policy of life-long learning. This creates much stress and uncertainty, and, in the case of less dedicated faculty members, may lead to teaching that is not of an acceptable standard or quality. This in turn obviously places additional stress on everyone. Faculty members tend to take their own training very seriously, but this is unfortunately not necessarily always the case. Change management is, therefore, a serious issue and quality control is extremely important. Heads of department play an important role in this. A general system of external examiners and regular external evaluations, however, tend to help departments stay on track and ensure that their teaching and research is of an acceptable quality.

\section{Conclusion}

This paper has brought to the fore several fundamental issues:

- The comprehensive and inclusive coverage of LIS education and training in Africa, which includes developments and issues in Francophone, Lucophone, Arabic and Spanish speaking countries is essential. This invites a collaborative publication involving LIS educators from all these areas.

- Although there are variations, there are common trends in the growth and development of LIS schools that include periodic curriculum reviews and revision, increased application and use of ICTs, decreasing or increasing student numbers, mergers and re-orientations, relocation of LIS programmes, expansion and closure.

- The numbers of LIS schools are increasing within countries where such schools already exist and new schools are emerging in countries where such schools never previously existed. This expansion contradicts views that the LIS job market is growing smaller or that the market is shrinking. However, in South Africa, a number of LIS schools have closed. The authors note that some expansions are not necessarily justified by market needs.

- Articulation of LIS schools is varied by the type of qualification programmes offered, duration of programmes and credit requirements, levels of qualifications, mode of instruction and the orientation of LIS schools. These trends are not common to LIS schools in Africa alone.

- LIS schools no longer focus on the education and training of librarians to work in libraries as was the case before, as libraries alone cannot sustain the employment needs of LIS graduates. Thus, curricula of many LIS schools currently target the emerging or broader information market. This probably explains why specific LIS schools have grown in some countries.

- There is strong evidence that curricula and qualifications of LIS schools in the region have kept minimum content, core subjects and credit requirements for LIS education and training internationally. 
- Although the integration of ICTs in LIS curricula is still problematic, largely due to resource support, most LIS schools in the region have integrated ICT in their curricula and are implementing ICTs in teaching, learning and research processes.

- In order to make LIS education relevant and current, and also for the purposes of viability of some LIS schools, there is a strong integration of new courses such as knowledge management, information literacy, multimedia, media and publishing studies, records management and basic computer technology into LIS curricula in general or as separate degree qualification programmes.

- The major challenges facing LIS education and training (in addition to the issues already mentioned) include the regulation of student numbers, knowledge and diversification of LIS job markets, funding of LIS schools and the development of technology infrastructures both in quantity and quality, allowing efficient access and the development of continuing education and short courses to provide new knowledge, skills and attitudes to LIS workers.

From the above descriptions, it is evident that LIS schools have, to a greater or lesser extent, been redesigning their curricula to keep track of the latest developments in the information world and keep their teaching market-related. Information retrieval has always been a core component of LIS, and this has been expanded to online information retrieval, web-based IR and database searching. Another core component is information organization, and in addition to traditional cataloguing and classification, students now also study the principles of metadata, Dublin Core and other metadata schema, etc. Courses on information management were introduced many years ago, and this has been extended by adding knowledge management. Computer literacy and information literacy in the computerized environment have been added. Numerous courses on ICT have also been added. Many specialization options have been added, and new programmes have been developed to provide opportunities for even further specialization. In many cases, departments have changed their names to reflect these new focus areas and extensions, and in many cases departments have realigned themselves within their universities.

It is evident that LIS schools have taken the challenges of the changing information environment very seriously, and have adapted their curricula, their names and their institutional alignments to reflect these changes. 
openUP (March 2007)

Table I Programmes available in LIS Schools in Eastern Central and Southern Africa (ECSA)

\begin{tabular}{|c|c|c|c|}
\hline Kinds of programmes & $\begin{array}{l}\text { LIS schools } \\
\text { Abbreviation }\end{array}$ & $n$ & $\%$ \\
\hline \multicolumn{4}{|l|}{ 1. Undergraduate - Certificate level: } \\
\hline i. Certificate in Library and Information Studies/Science & SLADS/EP/HP/KP/EASLIS/STTL/TSA/UB & 6 & 21 \\
\hline ii. Certificate in Information Science & KSPS & 1 & 3 \\
\hline iii. Certificate in School Librarianship & $\mathrm{UB}$ & 1 & 3 \\
\hline iv. Certificate in Health Information and Records Mgt. & $\mathrm{HP}$ & 1 & 3 \\
\hline v. Certificate in Archives and Records Mgt/Administration & $\mathrm{HP} / \mathrm{KP} / \mathrm{UB}$ & 3 & 10 \\
\hline vi. Higher Certificate in Library and Information Science & TSA & 1 & 3 \\
\hline \multicolumn{4}{|l|}{ 2. Undergraduate - Diploma level: } \\
\hline Diploma in Library Studies & TSA/UG/USL & 3 & 10 \\
\hline Diploma in Information Science/Studies & EP/ KP/KSPS/STTL/UoN/UNISA & 6 & 21 \\
\hline Diploma in School Librarianship & $\mathrm{HP} / \mathrm{UB} / \mathrm{UN}$ & 3 & 10 \\
\hline Diploma in Library/Information Science/Management & BUN/DIT/EASLIS/UB & 4 & 14 \\
\hline Diploma in Archives and Records Mgt/Administration & SLADS/KP/EASLIS/UB/UG & 5 & 17 \\
\hline Diploma in Library, Archives and Documentation Studies & HP/SLADS & 2 & 7 \\
\hline Diploma in Information Technology/Computers & STTI & 1 & 3 \\
\hline Diploma in Youth and Children's Information Work & UNISA & 1 & 3 \\
\hline Advanced/Higher Diploma in Information Management & $\mathrm{BUN} / \mathrm{HP}$ & 1 & 3 \\
\hline \multicolumn{4}{|l|}{ 3. Undergraduate - Bachelors Degree level: } \\
\hline Bachelor of Library and Information Science & ASU/BUN/KSPS/EASLIS/UB/USL/UWCJUZ & 6 & 21 \\
\hline BSc/BA Information Science & MU/RAU/UG/UP/UNISA/UZ & 6 & 21 \\
\hline BA in Information Systems & KSPS/UB/UaS/ & 4 & 14 \\
\hline BA in Archival Science & UNISA & 1 & 3 \\
\hline BA in Arts \& Culture - Societal Information & UNISA & 1 & 3 \\
\hline Bachelor of Information Science (BIS) & UP & 1 & 3 \\
\hline Bachelor of Information Science and Technology & NUST & 1 & 3 \\
\hline Rachelor of Terhnohnov in I ihrarv/Information Science & DIT/TSA & ? & 7 \\
\hline & LIS schools & & \\
\hline Kinds of programmes & Abbreviation & $n$ & $\%$ \\
\hline \multicolumn{4}{|l|}{ 4. Postgraduate - Postgraduate Diploma: } \\
\hline Postgraduate Diploma in Library and Information Science & UCT/USL/UZ & 3 & 10 \\
\hline Postgraduate Diploma in Information Studies & UN & 1 & 3 \\
\hline Postgraduate Diploma in Records and Archives Mgt. & RAU/UN & 2 & 7 \\
\hline Postgraduate Diploma in School Library Services/Science & KSPS/UZ & 1 & 3 \\
\hline Postgraduate Diploma in Museology & UN & 1 & 3 \\
\hline \multicolumn{4}{|l|}{ 5. Postgraduate - Honours Bachelor Degree: } \\
\hline Honours (Bachelor) degree in Library and Info. Science & UCT/UP/UZ & 2 & 7 \\
\hline Honours (Bachelor) degree in Information Science & UP/UNISA/UoS/UZ & 2 & 7 \\
\hline Honours (BA) in Archival Science & RAU/UNISA & 2 & 7 \\
\hline \multicolumn{4}{|l|}{ 6. Postgraduate - Masters Degree: } \\
\hline & ARCIS/EASLIS/OIU/UB/UCT/UDSM/ & & \\
\hline MA/MSc. Library/Information Science & UG/UN/USL/UNISA/UWC/UZ & 12 & 41 \\
\hline Master of Library and Information Science & ASU/BUN & 2 & 14 \\
\hline Master of Information Science & RAU/UP/UNISA/UOS & 4 & 14 \\
\hline MPhil - Library/Information Science & ARCIS/MU/UCT/UG/UaS & 5 & 17 \\
\hline Master of Technology in Library/Information Science & TSA & 1 & 3 \\
\hline Master of Education (M.ED) -LIS & KU & 1 & 3 \\
\hline \multirow[t]{2}{*}{ MA Archival Studies } & UG & 1 & 3 \\
\hline & LIS schools & & \\
\hline Kinds of programmes & Abbreviation & $n$ & $\%$ \\
\hline \multicolumn{4}{|l|}{ 7. Postgraduate - Doctoral Degree: } \\
\hline $\mathrm{PhD}$ - Library/Information Science & BUN/OIU/UB/UCT/UDSM/UG/UN/UP & 7 & 24 \\
\hline DPhil & ARCIS/MU/RAU/UB/UP/UNISA/UaS/UZ & 8 & 28 \\
\hline $\mathrm{PhD}$ Computer Science & UP & 1 & 3 \\
\hline
\end{tabular}

Note: $n=29$

Source: Ocholla and Minishi-Majanja (2004, pp. 58-59). Some of these abbreviations are created for this study. SU = Abia State University, Department of Library and Information Science, ARCIS = African Research Centre for Information Science, SLADS = Bagamoyo School of Library, Archives and Boumentation Studies; $\mathrm{BUN}$ = Bayero University, Nigeria, DLIS; DIT = Durban Institute of Technology, DLS; EP = Eldoret Polytechnic, Small
Business Centre; $\mathrm{HP}=$ Harare Polytechnic, Department of Library and Information Science KP = Kenya Polytechnic, Department of Information and Liberal Studies; KSPS = Kenya School of Professional Studies, Dept. of Information Science; KU = Kenyatta University, Department of Library Studies; EASLIS = Makerere University, East African School of LIS; MU = Moi University, Faculty of Information Sciences; OIU = Omdurman Islamic University, DLIS; RAU = Rand Afrikaans University, Department of Information Studies; STTI = Sigalagala Technical Training Institute, Dept. of Information \& Technology; TSA = Technikon South Africa, Department of Library and Information Studies; UB = University of Botswana, Department of Library and Information Studies; UCT = University of Cape Town, Dept. of Information and Library Studies; UDSM = University of Dar-es.Salaam, Department of Information Studies; UG = University of Ghana, Department of Information Studies; UoN=University of Nairobi, Department of Information Studies; UN = University of Natal, Department of Information Studies; UP = University of Pretoria, Department of Information Science, USL = University of Sierra Leone, Institute of Library, Information \& Communication Studies, UNISA = University of South Africa, Department of Information Science; US = University of Stellenbosch, Department of Information Science; UWC = University of Western Cape, Department of Library and Information Science; UNIZUL = University of Zululand, Department of Library and Information Science; NUST = Zimbabwe National University of Science and Technology, DLIS. Overall, paraprofessional programmes are offered in 16 ( 55 percent) of the LIS schools, undergraduate degree. Because of mergers of South African universities the higher education landscape has changed considerably; for instance, Rand Afrikaans University has merged with a technikon to become the University of Johannesburg, University of Natal has merged and the name was changed to the University of KwaZulu-Natal, UNISA merged with Technikon SA and retained its name UNISA 
openUP (March 2007)

Table II Population of LIS Schools in Eastern, Central and Southern Africa as at February-June 2003

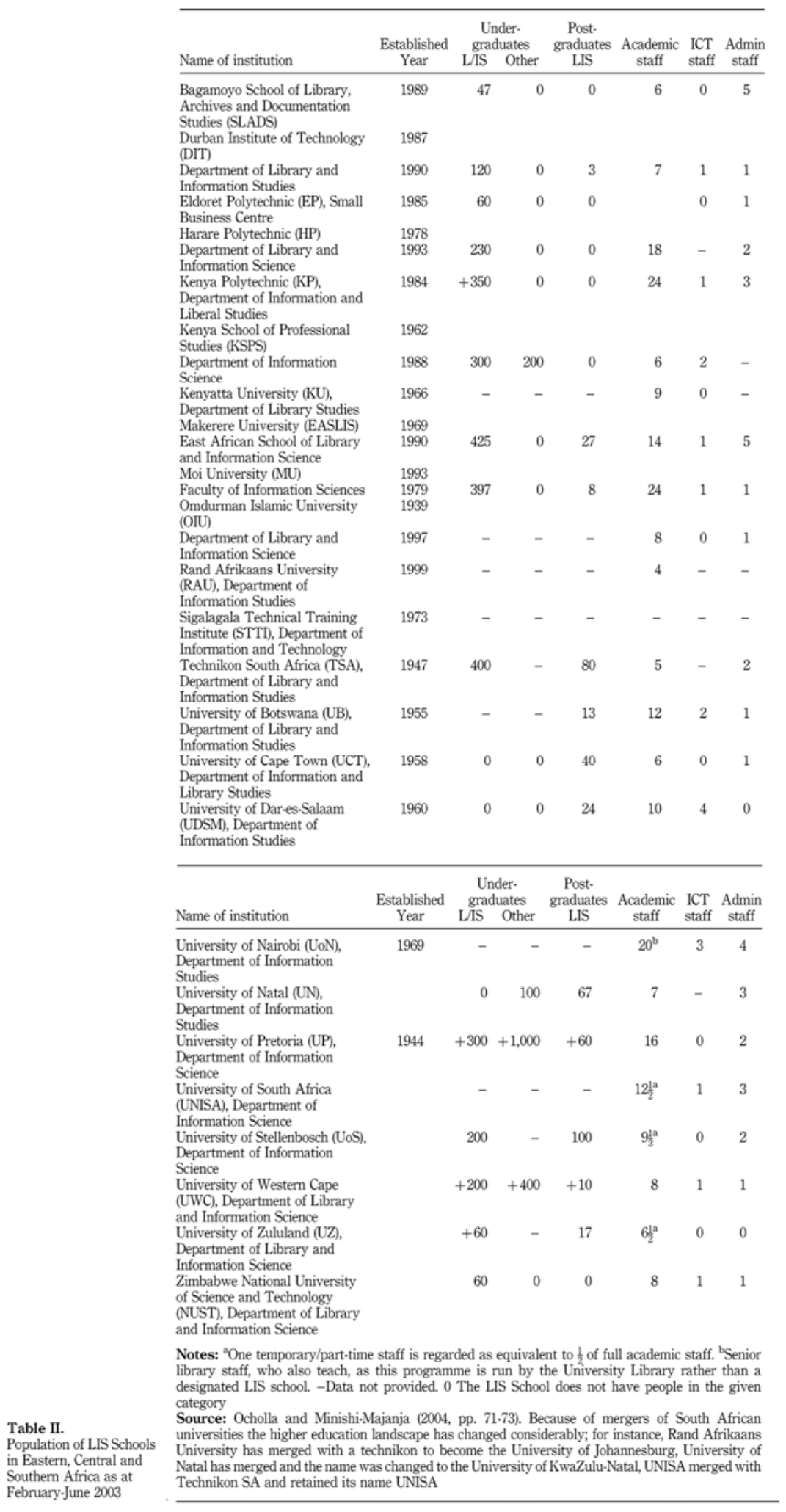




\section{References}

Aina, L.O. (1995), Who's Who in Library and Information Science Training Institutions in Africa, Archlib and Information Services, Ibadan.

Association of College and Research Libraries (2000), Association of College and Research Libraries Information Literacy and Competency Standards for Higher Education, ALA, Chicago, IL.

Bock, G. (1987), "Synopsis of existing and projected training programmes in the field of information studies at selected African institutions", in Bock, G., Huttemann, L. (Eds), Curriculum Adjustment in Information Studies Training Programmes in Africa, DSE, Bonn, (dok 1462 A/a-Se25.09.87).

Gupta, S., Gupta, D. (1993), "Development of library education in South Africa", Journal of Education for Library and Information Science, Vol. 34 pp.253.

Issak, A. (2006), Public Libraries in Africa: A Report and Annotated Bibliography, International Network for the Availability of Scientific Publications (INASP), Oxford, available at: www.inasp.ac.uk (accessed 1 May 2006).

Kaniki, A.M. (1997), "Continuing education and training programmes for library and information personnel in South Africa's educational institutions", Education for Information, Vol. 15 pp.1-15.

Kigongo-Bukenya, I. (2003), "Towards a viable curriculum: a comparative study of curricula at the east African School of Library and Information Science and the departments of Library and Information Studies of the Universities of Wales, Botswana and Cape Town", Education for Information, Vol. 21 No.2/3, pp.113-48.

Minishi-Majanja, M. (2003), "Mapping and auditing information and communication technologies in library and information science education in Africa: a review of the literature", Education for Information, Vol. 21 No.2/3, pp.159-79.

Minishi-Majanja, M. (2004), "Information and communication technologies in library and information science education in South Africa", Mousaion, Vol. 22 No.2, pp.150-71.

Minishi-Majanja, M., Ocholla, D.N. (2003), "Information and communication technologies in library and information science education in Kenya", Education for Information, Vol. 21 No.4, pp.243-62.

Minishi-Majanja, M., Ocholla, D.N. (2004), "Auditing of information and communication technologies in library and information science education in Africa", Education for Information, Vol. 22 No.3/4, pp.187-206.

Ocholla, D.N. (2000), "Training for library and information studies: a comparative overview of LIS education and in Africa", Education for Information, Vol. 18 pp.33-52. 
Ocholla, D.N. (2001), "Curriculum response to a changing national and international information environment: theoretical and methodological paradigms on review and revision", Education for Information, Vol. 19 No.2, pp.143-67.

Ocholla, D.N. (2003), "An overview of the information and communication technologies (ICT) in the LIS schools of Eastern and Southern Africa", Education for Information, Vol. 21 No.2/3, pp.181-94.

Ocholla, D.N. (2005), “An analysis of the job market in library and information services in South Africa: some thoughts and empirical evidence”, paper presented at the 9th LIASA (RETIG) Annual Conference, 25-30 September 2005, Nelspruit, Mpumalanga.

Ocholla, D.N., Minishi-Majanja, M. (2004), “An overview of LIS education and training in Eastern, Central and Southern Africa Region: challenges and opportunities”, Proceedings and Submitted Papers of the Library and Information Schools Network of Eastern, Central and Southern Africa (LISNET-ECSA) Workshop, Kampala, 3-4 July, 2004, pp.53-70.

Raju, R. (2005), "LIS education and training in South Africa: a historical review", South African Journal of Libraries and Information Science, Vol. 71 No.1, pp.74-84.

Sitzman, G.L. (1988), African Libraries, Scarecrow Press Inc., Metuchen, NJ.

Snyman, R. (2000), "Employment market for information professionals in South Africa”, paper presented at the LIASA Conference, Durban, 26-29 October.

Sturges, P., Neill, R. (1990), The Quiet Struggle. Libraries and Information for Africa, Mansell Publishing Limited, London.

University of Botswana (2005/2006), Department of Library \& Information Studies Handbook, University of Botswana, Gaborone.

Van Aswegen, E.S. (1997), "Menials or managers? A decade of library and information science education at Cape Technikon", South African Journal of Library and Information Science, Vol. 65 No.2, pp.53-9.

\section{About the authors}

Dennis Ocholla is Professor and Head of the Department of Library and Information Science, at the University of Zululand, South Africa. He is the corresponding author and can be contacted at: docholla@pan.uzulu.ac.za

Theo Bothma is Professor in the Department of Information Science at the University of Pretoria, South Africa. 